\title{
Can rapeseed oil replace olive oil as part of a Mediterranean-style diet?
}

\author{
Richard Hoffman ${ }^{1 *}$ and Mariette Gerber ${ }^{2}$ \\ ${ }^{1}$ School of Life and Medical Sciences, University of Hertfordshire, Hatfield AL1O 9AB, UK \\ ${ }^{2}$ Cancer Institute, 34298 Montpellier, Cedex 5, France
}

(Submitted 6 May 2014 - Final revision received 10 August 2014 - Accepted 14 August 2014-First published online 17 October 2014)

\begin{abstract}
The present narrative review compares evidence from experimental, epidemiological and clinical studies of the health benefits of rapeseed oil (RO) (known as canola oil) and olive oil (OO) in order to assess whether rapeseed oil is suitable as a sustainable alternative to OO as part of a Mediterranean-style diet in countries where olive trees do not grow. From epidemiological studies, the evidence for cardiovascular protection afforded by extra-virgin $\mathrm{OO}$ is 'convincing', and for cancers 'limited-suggestive', especially oestrogen receptor-negative breast cancer, but more studies are required in relation to cognitive impairment. Evidence for RO is limited to short-term studies on the biomarkers of risk factors for CVD. Any benefits of RO are likely to be due to $\alpha$-linolenic acid; however, it is prone to oxidation during frying. We conclude that due to a lack of evidence from observational or intervention studies indicating that RO has comparable health benefits to extra-virgin $\mathrm{OO}, \mathrm{RO}$ cannot currently be recommended as a suitable substitute for extra-virgin OO as part of a Mediterranean-style diet.
\end{abstract}

Key words: Rapeseed oil: Canola oil: Olive oil: Mediterranean diet

The traditional Mediterranean diet (MD) is widely recognised as one of the healthiest in the world, and it is likely that more widespread adoption of this diet in non-Mediterranean countries would lead to a significant reduction in the incidence of many chronic diseases ${ }^{(1)}$. Some health organisations in non-Mediterranean countries now recommend a MD. For example, in the UK, a MD is recommended by the NICE (National Institute for Health and Care Excellence) for secondary prevention following a myocardial infarction ${ }^{(2)}$. However, despite this type of targeted advice, there is only limited promotion of a MD to the general population in non-Mediterranean countries $^{(3)}$, and campaigns for healthy eating tend to focus on promoting diets that are compatible with the cultural heritage of a people. For example, Public Health England promotes the Eatwell Plate, a dietary pattern modelled on a healthy UK-based $\operatorname{diet}^{(4)}$, and in Norway, the traditional Norwegian diet has been promoted as being more appropriate for this country than adopting a $\mathrm{MD}^{(5)}$.

Nevertheless, it can be argued that the well-proven health benefits of the MD justify it being more widely promoted in non-Mediterranean countries. Promoting a MD in nonMediterranean countries is a viable public health approach since there is usually good compliance to this diet by nonMediterranean individuals who adopt it, and, in general, eating habits in many countries are becoming more flexible ${ }^{(6,7)}$. In addition, local produce can be used, rather than foods that only grow in Mediterranean countries, since food choices for a MD are mostly based on food groups, such as 'fruits' or 'vegetables', rather than on specific foods ${ }^{(8)}$. Indeed, it has been argued that many features of recommended dietary patterns in Northern Europe, such as high consumption of fruit and vegetables and low consumption of meat, are quite similar to the $\mathrm{MD}^{(9)}$.

One exception to the generalised recommendation of food groups, rather than specific foods, is to consume olive oil (OO) as the main source of added fat. Indeed, it is the consumption of OO - more than any other single factor that distinguishes the traditional MD from other dietary patterns $^{(10)}$. However, adopting $\mathrm{OO}$ as the main dietary fat as part of a MD in non-Mediterranean populations may present an obstacle since it is relatively costly compared with other cooking oils, and consumption of $\mathrm{OO}$ in non-Mediterranean populations is low ${ }^{(11)}$. Consuming large quantities of $\mathrm{OO}$ in non-Mediterranean countries also raises the issues of food security. The food security agenda aims to increase the production of foods within national borders in order to guarantee food production independent of international influences. Since olive trees only grow in Mediterranean-type climates, this may not be compatible with food security issues, although this is less of an issue between European Union countries that share interdependent policies.

Abbreviations: ALA, $\alpha$-linolenic acid; ER, oestrogen receptor; EVOO, extra-virgin olive oil; FA, fatty acid; MD, Mediterranean diet; OMWW, olive mill waste water; OO, olive oil; RO, rapeseed oil; VOO, virgin olive oil.

*Corresponding author: R. Hoffman, fax + 441707 285046, email r.hoffman@herts.ac.uk 
The health benefits of $\mathrm{OO}$ are attributed both to its high content of the MUFA oleic acid ${ }^{(12)}$ and to various minor components $^{(13)}$. Rapeseed oil (RO) (known as canola oil in the USA, Canada and some other countries) is a potential substitute for OO since it has a similar MUFA content to that of OO and its overall fatty acid (FA) profile is favourable due to a low content of SFA and a high content of PUFA, including $\alpha$-linolenic acid (ALA). Consumption of RO is now high in many non-Mediterranean countries, partly due to the low cost, and also because it is perceived as being a healthy oil. There is increasing substitution of $\mathrm{RO}$ for $\mathrm{OO}$, such as in recipes for the home cook, and in the UK, the NICE do not specify $\mathrm{OO}$ in their description of a MD but instead refer to 'vegetable oil', which in the UK generally refers to $\mathrm{RO}^{(2)}$. Hence, perhaps not surprisingly, consumption of $\mathrm{RO}$ in the UK may now be starting to displace that of $O O$ since $O O$ sales have seen their first fall in over 20 years ${ }^{(14)}$

Rapeseeds are widely grown, both for biofuel and for human consumption, in many European Union countries, Canada, China, Australia and India ${ }^{(15)}$. In the UK, rapeseeds are the only oilseeds harvested in significant quantities. In view of the relatively low cost and the ready availability of RO, we examine whether the health benefits of RO justify it replacing $\mathrm{OO}$ as part of wider recommendations for consumption of a MD in non-Mediterranean countries, and so ask whether $\mathrm{RO}$ can be regarded as an ersatz 'Northern OO' for the domestic consumer.

\section{Methods}

We used a narrative review approach, and searched electronic databases such as PubMed and Scopus up until April 2014. Keywords such as 'olive oil', 'virgin olive oil', 'rapeseed oil' and 'Canola' were used in combination with keywords such as 'composition' (and related words such as 'phenolics', 'antioxidants'), 'cardiovascular disease' (and related words such as 'coronary heart disease' and 'myocardial infarction'), 'cancer' and 'neurodegenerative disease' (and related words such as 'Alzheimer's disease' and 'dementia') and the study method (such as 'cohort' and 'meta analysis').

\section{Results \\ Composition}

Fats. In addition to a high MUFA content (mainly oleic acid), $\mathrm{OO}$ also contains a range of other $\mathrm{FA}^{(16)}$. The levels of various FA in OO vary quite widely between oils depending on factors such as the type of olive tree cultivar used for oil production (see Table 1). RO also has a high MUFA content, as well as considerably higher levels of ALA than OO (see Table 1). Consumption of ALA is linked to cardioprotective benefits (see below). However, RO also contains approximately $1 \%$ trans isomers of ALA, which are produced during the deodorisation step of oil production ${ }^{(17,18)}$. There is a well-established link between trans-fatty acid consumption and the increased risk of $\mathrm{CHD}^{(19)}$, and although the level in $\mathrm{RO}$ does not in
Table 1. Compositions of rapeseed oil and olive oil

\begin{tabular}{lcc}
\hline & Rapeseed oil & \\
\hline Main fatty acids $(\mathrm{g} / 100 \mathrm{~g})$ & & Olive oil $^{(16)}$ \\
Palmitic acid $(16: 0)$ & 3.6 & $7.5-20.0$ \\
Oleic acid $(18: 1)$ & 61.6 & $55-83$ \\
Linoleic acid $(18: 2)$ & 21.7 & $3.5-21.0$ \\
$\alpha$-Linolenic acid $(18: 3)$ & 9.6 & $0.0-1.0$ \\
Minor components $(\mathrm{g} / \mathrm{kg})$ & & \\
Squalene & 0.28 & $0.7-12.0$ \\
Carotenoids & 0.01 & $0.001-0.01$ \\
Phytosterols & 6.9 & $1.0-2.3$ \\
Tocopherols & $0.43-2.68$ & $0.036-0.37$ \\
Phenolics & 0.05 & $0.05-0.8$ \\
\hline
\end{tabular}

itself constitute a health risk, it is desirable to keep the levels of trans-fatty acids to a minimum.

$\mathrm{RO}$ is very low in SFA, comprising only approximately $6 \%$ of the total FA. This is about half the average content of SFA in $\mathrm{OO}$, and it has been argued that this gives RO an advantage over $\mathrm{OO}^{(20)}$. However, the quite low proportion of SFA even in OO means that it would not normally be a significant daily source of SFA compared with other dietary sources such as meat or dairy products. For example, $20 \mathrm{ml}$ OO contains $128 \mathrm{mg}$ SFA, giving $9.62 \mathrm{~kJ}(2.3 \mathrm{kcal})$ of energy as SFA. The current UK intake of SFA is $12.7 \%$ of the total energy intake $^{(21)}$. Hence, consumption of $20 \mathrm{ml}$ OO represents less than $1 \%$ of the average daily intake of energy in the UK from SFA $(0.9 \%$ total energy in women based on an intake of $8368 \mathrm{~kJ}(2000 \mathrm{kcal})$ and $0.7 \%$ total energy in men based on an intake of $10460 \mathrm{~kJ}(2500 \mathrm{kcal}))$.

Minor components. There are significant differences between the minor components in RO and extra-virgin olive oil (EVOO), due not only to the source of the oil but also to production methods. EVOO is produced using mild conditions that include pressing olive fruits at a low temperature, washing with water, filtration and centrifugation. These conditions retain many of the original components of the olives. The most abundant minor component is the hydrocarbon squalene, and there are smaller quantities of carotenoids, triterpenoids, phytosterols (e.g. $\beta$-sitosterol, $\Delta^{5}$-avenasterol and campesterol) and tocopherols (approximately 95\% $\alpha$-tocopherol) (Table 1). EVOO also contains a wide variety of phenolic compounds including secoiridoids (e.g. oleuropein) and their phenolic derivatives (e.g. tyrosol and hydroxytyrosol), flavonoids (e.g. luteolin and apigenin) and lignans (e.g. pinoresinol and acetoxypinoresinol). EVOO is the best quality $\mathrm{OO}$ and must meet predefined criteria in terms of sensory qualities and limits of acidity. Other OO have substantially lower levels of most of the minor components, and phenolic compounds, in particular, are reduced ${ }^{(16)}$.

Many potentially beneficial biological actions have been described for the minor components in EVOO. Phenolic compounds of EVOO reduce the markers of inflammation and oxidative stress in vitro and in vivo ${ }^{(22,23)}$. Squalene reduces oxidative stress in human mammary epithelial cells ${ }^{(24)}$. Lignans are phyto-oestrogens with possible anticancer activity ${ }^{(25)}$, and it is noteworthy that OO (both EVOO and other OO) has been found to be the major dietary source of lignans 
in participants of the Prevención con Dieta Mediterránea (PREDIMED) study ${ }^{(26)}$. Secoiridoids such as oleuropein and its derivatives are of particular interest in relation to the health benefits of EVOO since they are not found in other food plants.

Standard production of $\mathrm{RO}$ requires a far higher level of processing including solvent extraction of the oil from the pressed seeds, and refining by degumming, neutralisation, bleaching and deodorisation. As a consequence, most of the minor constituents that were originally present in the rapeseeds are significantly depleted in the oil. Some of the phytosterols (including $\beta$-sitosterol, campesterol and brassicasterol) and tocopherols (mainly $\alpha$ - and $\gamma$-tocopherol, in a ratio of approximately $1: 2$ ) are lost, as are most or all of the phenolic compounds originally present (including a high proportion of sinapic acid and its derivatives) ${ }^{(27)}$. Phytosterols are best known for their ability to reduce cholesterol uptake from the gut, although some, such as $\Delta^{5}$-avenasterol, possess antioxidant activity.

\section{Cooking}

Consumption of raw EVOO is often quite high in a Mediterranean cuisine, and this may be important since compositional changes can occur to oils during cooking (see below). Raw EVOO is used as a salad dressing or simply poured on bread, as a main ingredient in many dips and sauces and as an addition to stews at the end of cooking to enhance flavour. Whereas some people prize EVOO for its flavour, it is unclear whether the flavour of raw RO would be an acceptable substitute. $\mathrm{OO}$ is also consumed after frying and baking due to the oil being absorbed into the cooked food. Large quantities of $\mathrm{OO}$ are consumed in the lathera dishes of some eastern Mediterranean countries since the cooking oil in which vegetables are cooked is consumed as an integral part of the dish. OO is more commonly used for shallow frying (which typically requires an oil temperature of $140-160^{\circ} \mathrm{C}$ ) rather than deep frying $\left(180-190^{\circ} \mathrm{C}\right)$ due to its relatively low smoke point.

There can be significant thermal degradation of FA and minor components in oils during cooking, and this may potentially have detrimental health effects. Undesirable changes include the hydrolysis and polymerisation of TAG, the oxidation of FA and sterols, and the generation of trans-fatty acids. Lipid oxidation is influenced by various factors such as the type of food present, the proportion of the oil exposed to the air, and the amount of unsaturated fats in the oil. Oxidation increases with the degree of unsaturation: ALA $(18: 3 n-3)$ is 2.4 times more reactive than linoleic acid $(18: 2 n-6)$, which is forty times more reactive than oleic acid $(18: 1 n-9)^{(28)}$. This is of potential concern for RO due to its high ALA content. Prolonged and repeated deep frying with $\mathrm{RO}$, as may occur in commercial establishments, can also lead to the generation of quite high levels of trans-fatty acids ${ }^{(29)}$

Loss of antioxidants. During frying, antioxidants in oils are lost due to both direct thermal degradation and to being consumed during the thermal oxidation of unsaturated fats ${ }^{(30)}$. EVOO contains a favourable ratio of antioxidants: PUFA compared with other types of oils, and this reduces both the rate at which antioxidants are lost and the rate of lipid oxidation that occurs during frying ${ }^{(31,32)}$. Antioxidants in EVOO deplete at different rates, as demonstrated in a study by Gomez-Alonso et $a l^{(33)}$, who found that hydroxytyrosol was depleted to a far greater extent than tyrosol when EVOO was used for frying potatoes at $180^{\circ} \mathrm{C}$ for 10 min. Phenolic compounds in EVOO help stabilise vitamin E during heating, and vitamin $\mathrm{E}$, in turn, helps protect PUFA from oxidative degradation ${ }^{(31)}$.

Despite the losses of minor components due to frying, heated virgin olive oil (VOO) has been shown to retain beneficial effects on postprandial inflammation. VOO repeatedly heated to $180^{\circ} \mathrm{C}$ has been shown to suppress postprandial inflammation in obese subjects (determined as NF- $\mathrm{\kappa B}$ activation in peripheral blood monocytes) compared with a seed oil with a similar fat content (a blend of high-oleic acid sunflower oil and $\mathrm{RO})^{(34)}$. Although the heating protocol completely depleted hydroxytyrosol in VOO, other minor components, including some phenolic compounds, were retained.

In summary, although antioxidants in EVOO are reduced during frying, using EVOO rather than other types of OO for frying may be justified as a means to minimise the oxidation of the relatively low content of PUFA and to reduce postprandial inflammation. Antioxidants in EVOO have also been to shown to migrate into the food during cooking, and so may confer health benefits in the body ${ }^{(35,36)}$.

Antioxidants in $\mathrm{RO}$ include phytosterols, vitamin $\mathrm{E}$ and Coenzyme Q, although levels of phenolic compounds are very low compared with those in EVOO (see Table 1). Vitamin E content was reduced by two-thirds when RO was heated at $150^{\circ} \mathrm{C}$ for $6 \mathrm{~h}^{(30)}$, and vitamin $\mathrm{E}$ was also significantly depleted using conditions designed to replicate RO being used for deep frying ${ }^{(37)}$. The concentration of ALA in RO is a major determinant of the extent of FA oxidation ${ }^{(38)}$. The relatively low ratio of antioxidants:PUFA in RO may lead to significant losses of antioxidants and increase lipid peroxidation, although this will depend on the time period and temperature used for frying. The more favourable balance between antioxidants and PUFA in EVOO may retain more antioxidants.

Generation of toxic compounds. Insufficient protection of PUFA from oxidation leads to their conversion to hydroperoxides, and these may break down to various volatile compounds ${ }^{(39)}$. Some compounds, such as acetaldehyde and acrolein (2-propenal), are toxic. Acetaldehyde is classified as a carcinogen by the European Union, whereas the main health effect of exposure to acrolein is irritation of the eyes, the mucosae and the skin ${ }^{(40)}$. It is therefore desirable to minimise the exposure to toxic volatile compounds present in cooking fumes produced during frying. Fullana et al. ${ }^{(41)}$ reported that acetaldehyde production at $180^{\circ} \mathrm{C}$ was twice as high for $\mathrm{RO}$ as for either $\mathrm{OO}$ or $\mathrm{VOO}$, although the levels from all oils were low, and no acetaldehyde emissions were detected by Katragadda et $a l^{(42)}$ at $180^{\circ} \mathrm{C}$. Production of acrolein by $\mathrm{RO}$ at $180^{\circ} \mathrm{C}$ was found to be approximately five times higher than acrolein production by either EVOO or $\mathrm{OO}^{(41,42)}$. This is probably due to the high ALA content of RO since recent studies have indicated that thermal degradation of ALA is the main source of acrolein in $\mathrm{RO}^{(43,44)}$. The presence 
of antioxidants in EVOO such as chlorophylls, pheophytins and carotenoids may also reduce acrolein formation compared with $\mathrm{RO}^{(45)}$. Despite the generation of some toxic volatile compounds, especially by RO, there is no evidence that, under normal domestic conditions, using fresh RO for shallow frying is likely to pose a health risk through inhalation.

In summary, there exists a clear advantage for EVOO over $\mathrm{RO}$ in terms of the former's richer composition, limited processing without solvent extraction and deodorisation, and safety of use in cooking.

\section{Health}

Various studies have assessed the health benefits of $\mathrm{OO}$ and RO. Several expert committees have described the basis for making a robust judgement of a causal relationship between a nutrient or food and disease risk ${ }^{(46,47)}$. Consistency between several observational studies is necessary, with prospective studies being favoured over case-control studies. When available, there should be randomised controlled trials of sufficient size and duration, with more weight being given to disease incidence as an endpoint rather than to biological markers. Experimental studies, both in vivo and in vitro, can provide biological plausibility. We follow these guidelines for assessing the respective health benefits of $\mathrm{OO}$ and RO. Epidemiological studies are summarised in Tables 2 and 3 .

\section{Olive oil and health}

$C V D$. Many epidemiological studies, including randomised controlled trials, have shown that a Mediterranean dietary pattern that includes $\mathrm{OO}$ is convincingly associated with a reduced risk of CVD, and is probably associated with a reduced risk of certain cancers and neurodegenerative diseases (reviewed in Hoffman \& Gerber ${ }^{(48)}$ ). Only a few of these epidemiological studies have focused on the specific effect of OO. Ancel Keys, the pioneer advocate of the MD, first proposed that it was the ratio of MUFA:SFA that was the key component for the health benefits of the $\mathrm{MD}^{(49)}$. Although this suggested that the importance of OO was to provide MUFA, later on it was established that MUFA from sources other than OO (animal fat containing $40-45 \%$ of MUFA) did not have the same beneficial effect ${ }^{(50)}$.

Consequently, studies were undertaken to decipher the specific effect of OO. In the Three-City Study, individuals with intensive use of $\mathrm{OO}$ showed a lower risk of stroke compared with those who never used $\mathrm{OO}^{(51)}$. In the Italian-EPIC cohort, women with a high consumption of OO had reduced incidence risk of non-fatal and fatal myocardial infarction ${ }^{(52)}$, although it should be noted that this study has been criticised because it was not fully adjusted. In another analysis conducted on the EPIC population in Spain, a high intake of OO decreased the risk of overall mortality by $26 \%$ and of CVD deaths by $44 \%{ }^{(53)}$. A recent meta-analysis by MartinezGonzalez et al. ${ }^{(54)}$ comparing high $v$. low intake of $\mathrm{OO}$ found a significant risk reduction for stroke, but the risk reduction for $\mathrm{CHD}$ was not significant (Table 2).

In the studies included in the meta-analysis by MartinezGonzalez et $a l^{(54)}$, only that by Buckland et al. ${ }^{(55)}$ distinguished between $\mathrm{OO}$ and EVOO. In this well-conducted study from Spain, there was a reduction in CVD incidence of $7 \%$ for each $10 \mathrm{~g}$ increase of $\mathrm{OO}$ per $8.4 \mathrm{MJ}$ ingested, and this effect was greater for EVOO (risk reduction 14\%). The role of EVOO was examined in the PREDIMED randomised control trial. Participants at high vascular risk were randomly allocated to three groups. Of these groups, two received a typical MD supplemented with either EVOO (1 litre/week) or mixed nuts $(30 \mathrm{~g} / \mathrm{d})$. The third control group was advised to follow a low-fat diet. In the two groups that received advice on the MD, the risk of CVD (myocardial infarction, stroke or death from CVD) was reduced by approximately $30 \%{ }^{(56)}$. Recent additional analysis of the PREDIMED study provides further evidence for a superior beneficial effect of EVOO $v$. non-virgin OO on CVD risk. This observational prospective cohort analysis was based on baseline consumption of $\mathrm{OO}$, i.e. before randomisation into groups. In individuals at high cardiovascular risk, there was a statistically significant reduction in total cardiovascular risk and stroke (but not myocardial infarction) for total OO consumption or for consumption of EVOO, but not for consumption of nonvirgin $\mathrm{OO}^{(57)}$ (see Table 2). These results remained even after adjusting for adherence to a MD. The results highlight the possible important contribution of minor components in EVOO to cardiovascular protection.

Short-term studies with cardiovascular risk factors as end-points have also suggested that phenolic compounds are important for the cardiovascular benefits of VOO. For example, the EUROLIVE (the effect of olive oil consumption on oxidative damage in European countries) study, comparing OO high and low in phenolic compounds, found a linear increase in HDL-cholesterol levels for low-, mediumand high-polyphenol $\mathrm{OO}$, and a linear decrease in oxidised LDL levels ${ }^{(58)}$. A reduction in LDL oxidation for EVOO with a minimum hydroxytyrosol content is the basis for a recent health claim issued by the European Food Safety Authority for the health benefits of $\mathrm{OO}^{(59)}$. VOO, as part of a Mediterranean diet, has also been shown to reduce the levels of circulating inflammatory molecules associated with increased cardiovascular risk $^{(60)}$.

Experimental models, both in vitro and in vivo, have suggested that VOO can favourably alter many stages in atherosclerosis. VOO has been shown to reduce atherosclerosis in apoE-deficient mice and hamsters ${ }^{(61)}$. Anti-inflammatory activities of minor components in VOO include reducing prostacyclin synthesis in human vascular smooth muscle cells, inhibiting cyclo-oxygenases ${ }^{(62)}$, and inhibiting endothelial adhesion molecule expression ${ }^{(63)}$. Phenolic compounds also have favourable effects on haemostasis ${ }^{(64)}$

Although many studies have indicated that cardiovascular risk is reduced when MUFA replaces dietary SFA or carbohydrates $^{(65)}$, epidemiological evidence for a specific contribution of oleic acid in OO to cardiovascular protection is limited. However, short-term feeding studies in human subjects have suggested that one benefit of diets rich in $\mathrm{OO}$ is that they do not have the adverse effects on postprandial inflammation and haemostasis compared with diets rich in $\mathrm{SFA}^{(12)}$. OO has also been shown to have beneficial hypotensive effects in short-term feeding studies ${ }^{(12)}$, and oleic acid 
Table 2. Recent epidemiological studies on the health effects of olive oil (OO)

\begin{tabular}{|c|c|c|c|c|c|c|c|c|c|}
\hline Study & $\begin{array}{l}\text { Disease } \\
\text { outcome }\end{array}$ & Study design & $\begin{array}{l}\text { Subjects/cases } \\
\text { and age range }\end{array}$ & OO type & $\begin{array}{l}\text { Exposure } \\
\text { measurement }\end{array}$ & Statistical adjustments & Intake categorisation & Relative risk ( $95 \% \mathrm{Cl}$ ) & Trend \\
\hline $\begin{array}{l}\text { Samieri et al. }{ }^{(51)} 2011 \\
\text { (Three-City Study, } \\
\text { France) }\end{array}$ & Stroke & $\begin{array}{l}\text { Prospective } \\
\text { Median follow-up } \\
\text { of } 5.25 \text { years }\end{array}$ & $\begin{array}{l}7625 / 148 \\
\geq 65 \text { years } \\
\quad(37.7 \% \text { male })\end{array}$ & Total ০० & $\begin{array}{l}\text { Frequency of } \\
\text { broad } \\
\text { categories } \\
\text { of foods } \\
\text { and preferred } \\
\text { added fat }\end{array}$ & $\begin{array}{l}\text { Cox model } \\
\text { (1) Age, sex, education, } \\
\text { study centre } \\
\text { (2) Foods of the Med diet; } \\
\text { other oils; animal fat; } \\
\text { smoking status; alcohol } \\
\text { consumption; PA; other } \\
\text { stroke risk factors; BMI, } \\
\text { TAG, total cholesterol }\end{array}$ & $\begin{array}{l}\text { Moderate (dressing or } \\
\text { cooking), intensive } \\
\text { users (dressing and } \\
\text { cooking) } v \text {. no users }\end{array}$ & $\begin{array}{l}\text { Intensive users: } 0.59 \\
\quad(0.37,0.94)\end{array}$ & 0.02 \\
\hline $\begin{array}{l}\text { Bendinelli et al!(52) } 2011 \\
\text { (EPICOR study, Italy) }\end{array}$ & $\begin{array}{l}\text { Myocardial } \\
\text { infarction }\end{array}$ & $\begin{array}{l}\text { Prospective } \\
\text { Follow-up of } \\
\text { average } \\
7.85 \text { years }\end{array}$ & $\begin{array}{l}29689 / 144 \\
35-74 \text { years } \\
\quad \text { (women) }\end{array}$ & Total OO & $\begin{array}{l}\text { Validated EPIC } \\
\quad \text { FFQ }\end{array}$ & $\begin{array}{l}\text { Cox model } \\
\text { (1) Energy } \\
\text { (2) Education, fruit, vegetables, } \\
\text { meat, smoking status; } \\
\text { alcohol consumption, } \\
\text { body weight and waist } \\
\text { circumference }\end{array}$ & $\geq 31.2 \mathrm{v} . \leq 15.9 \mathrm{~g} / \mathrm{d}$ & $0.56(0.31,0.99)$ & 0.04 \\
\hline $\begin{array}{l}\text { Buckland et al.(53) } 2012 \\
\text { (EPIC-Spain) }\end{array}$ & $\begin{array}{l}\text { Overall and } \\
\text { CVD mortality }\end{array}$ & $\begin{array}{l}\text { Prospective } \\
\text { Follow-up of } \\
8-12 \text { years }\end{array}$ & $\begin{array}{l}\text { 40622/1915 } \\
\text { deaths/416 CVD } \\
\text { 29-69 years (women) }\end{array}$ & Total OO & $\begin{array}{l}\text { Validated dietary } \\
\text { history } \\
\text { questionnaire } \\
\text { of } 600 \text { items }\end{array}$ & $\begin{array}{l}\text { Cox model } \\
\text { (1) Age, sex, study centre } \\
\text { (2) Non-nutritional factors: } \\
\text { BMI, waist circumference, } \\
\text { smoking status; alcohol } \\
\text { consumption; PA } \\
\text { (3) Foods of the Med diet score }\end{array}$ & $\begin{array}{l}29.4 \mathrm{~g} \text { per d} / 8.4 \mathrm{MJ} v . \\
\quad<14.9 \mathrm{~g} \text { per d} / 8.4 \mathrm{MJ}\end{array}$ & $\begin{array}{l}\text { Overall mortality: } 0.74 \\
(0.64,0.87) \\
\text { CVD mortality: } 0.56 \\
(0.40,0.79)\end{array}$ & $\begin{array}{l}<0.001 \\
<0.001\end{array}$ \\
\hline $\begin{array}{l}\text { Buckland et al.(55) } 2012 \\
\text { (EPIC-Spain) }\end{array}$ & CHD incidence & $\begin{array}{l}\text { Prospective } \\
\text { Follow-up of } \\
8-12 \text { years }\end{array}$ & $\begin{array}{l}40142 / 587 \\
29-69 \text { years } \\
\quad(38 \% \text { male) }\end{array}$ & $\begin{array}{l}\text { Total OO } \\
\text { EVOO }\end{array}$ & $\begin{array}{l}\text { Validated dietary } \\
\text { history } \\
\text { questionnaire } \\
\text { of } 600 \text { items }\end{array}$ & $\begin{array}{l}\text { Cox model } \\
\text { (1) Age, sex, study centre } \\
\text { (2) Non-nutritional factors: } \\
\text { BMI, waist circumference, } \\
\text { smoking status; alcohol } \\
\text { consumption; PA } \\
\text { (3) Foods of the Med diet } \\
\text { score, excluding OO } \\
\text { and alcohol } \\
\text { (4) Goldberg exclusions }\end{array}$ & $\geq 28.9 \mathrm{v} .<10 \mathrm{~g}$ & $0.78(0.59,1.03)$ & 0.079 \\
\hline $\begin{array}{l}\text { Guasch-Ferré } \\
\text { et al. }{ }^{(57)} 2014 \\
\text { (PREDIMED, Spain) }\end{array}$ & $\begin{array}{l}\text { CVD events } \\
\text { and mortality }\end{array}$ & $\begin{array}{l}\text { Prospective } \\
\text { Follow-up of } \\
4.8 \text { years }\end{array}$ & $\begin{array}{l}7216 \text { subjects at risk } \\
\text { for CVD/227 } \\
\text { events/323 deaths } \\
67 \pm 6(42 \% \text { male })\end{array}$ & $\begin{array}{l}\text { Total OO, } \\
\text { non-virgin } \\
\text { OO, EVOO }\end{array}$ & $\begin{array}{l}\text { Validated dietary } \\
\text { history } \\
\text { questionnaire } \\
\text { of } 137 \text { items }\end{array}$ & $\begin{array}{l}\text { Cox model } \\
\text { (1) Age, sex, intervention } \\
\text { group } \\
\text { (2) Non-nutritional factors: } \\
\text { BMI, waist circumference, } \\
\text { smoking status; alcohol } \\
\text { consumption; PA; markers } \\
\text { of risk factors } \\
\text { (3) Med diet score, excluding } \\
\text { OO and alcohol }\end{array}$ & $\begin{array}{l}\text { Total OO: } 56 \cdot 9 \pm 10 \mathrm{v} \\
21 \cdot 4 \pm 8 \mathrm{~g} / \mathrm{d} \\
\text { EVOO: } 34.6 \pm 27 \cdot 4 \mathrm{v} \\
\quad 9 \cdot 1 \pm 11 \mathrm{~g} / \mathrm{d} \\
\text { Non-virgin OO: } \\
21.7 \pm 25 \cdot 1 \mathrm{v} \\
12.1 \pm 11.7 \mathrm{~g} / \mathrm{d}\end{array}$ & $\begin{array}{l}\text { CV event } \\
\text { Total OO: } 0.65 \\
(0.47,0.91) \\
\text { EVOO: } 0.61 \\
(0.44,0.85) \\
\text { Non-virgin OO: NS } \\
\text { CV mortality } \\
\text { Total OO: } 0.52 \\
\text { (0.73, } 0.96) \\
\text { EVOO: NS } \\
\text { OO: NS }\end{array}$ & $\begin{array}{r}0.01 \\
<0.01\end{array}$ \\
\hline
\end{tabular}


has been implicated in these effects since, in rat models, triolein (the main TAG in OO, consisting of three oleic acid moieties) has been shown to reduce blood pressure as effectively as $\mathrm{VOO}^{(66)}$.

Cancers. A beneficial effect of adherence to a MD (as assessed by a MD score) and reduced cancer risk is found to be greater in Mediterranean, rather than non-Mediterranean, populations ${ }^{(8)}$. The overall cancer mortality in the abovequoted Spanish study showed a relative risk of $<1$, but was non-significant ${ }^{(53)}$. In the PREDIMED study, no statistically significant associations were found between consumption of any type of $\mathrm{OO}$ and mortality from all types of cancer ${ }^{(57)}$. However, different cancer sites are characterised by different risk factors, and for some types of cancer, there are indications of a specific effect of $\mathrm{OO}$, and this is supported by several in vitro and in vivo experimental studies ${ }^{(67)}$. A meta-analysis of twenty-five studies reported risk reduction for upper digestive and respiratory tract cancers, breast and, possibly, colorectal and other cancer sites ${ }^{(68)}$. Similarly, a posteriori dietary pattern analysis has demonstrated a greater risk reduction in breast cancer when $O O$ was present in the pattern ${ }^{(69-71)}$ A more recent study addressed the question of $\mathrm{OO}$ and breast cancer in the Mediterranean countries of the EPIC (European Prospective Investigation into Cancer and Nutrition) study and observed a non-significant risk reduction in oestrogen receptor-negative $(\mathrm{ER}-)$ and progesterone receptor-negative breast cancers for a high intake of $\mathrm{OO}^{(72)}$. These cancers are independent from hormonal factors and differ from ER+ breast cancers in terms of risk factors. However, they represent only 25 to $30 \%$ of all breast cancers, and the lack of statistical power might explain the large CI observed in this study (see Table 2). This epidemiological observation has been supported by an experimental model showing that the OO phytochemical oleuropein is more cytotoxic for basal-like ER- MDA-MB-231 cells than for luminal ER+ MCF-7 cells ${ }^{(73)}$.

Neurodegenerative diseases. In the prospective Three-City Study, OO was associated with a decrease in cognitive impairment ${ }^{(74)}$. In participants of the PREDIMED study, consumption of some foods was independently associated with better cognitive function. Among them, total OO positively correlated with immediate verbal memory and EVOO with delayed verbal memory ${ }^{(75)}$. More recently, in the PREDIMED-Navarra trial, 285 participants at high vascular risk were randomly allocated to three groups: a MD supplemented with EVOO; a MD supplemented with mixed nuts; a low-fat diet. Lower mild cognitive impairment was observed in the EVOO group compared with the control group ${ }^{(76)}$. Participants assigned to the MD + nuts group did not differ from the control group. Various antioxidant and anti-inflammatory phenolic compounds in EVOO may contribute to these beneficial effects since oxidative stress and inflammation are associated with neurodegeneration ${ }^{(77)}$. More specific effects have also been described for phenolic compounds of EVOO. Tyrosol and hydroxytyrosol have been shown to decrease activation by $\beta$-amyloid of the pro-inflammatory transcription factor $\mathrm{NF}-\mathrm{\kappa B}$ in cultured neuroblastoma cells ${ }^{(78)}$. In mouse models of Alzheimer's disease where there is increased levels of $\beta$-amyloid, the EVOO phenolic compounds oleocanthal 
Table 3. Epidemiological studies on the health effects of dietary $\alpha$-linolenic acid (ALA)

\begin{tabular}{|c|c|c|c|c|c|c|c|c|}
\hline Study & $\begin{array}{l}\text { Disease } \\
\text { outcome }\end{array}$ & Study design & $\begin{array}{l}\text { Subjects/cases } \\
\text { and age range }\end{array}$ & $\begin{array}{l}\text { Exposure } \\
\text { measurement }\end{array}$ & Statistical adjustments & Intake categorisation & $\begin{array}{l}\text { Relative } \\
\text { risk* }(95 \% \mathrm{Cl})\end{array}$ & Trend \\
\hline $\begin{array}{l}\text { Folsom et al. }{ }^{(89)} \\
2004 \text { (lowa } \\
\text { Women's Health } \\
\text { Study, USA) }\end{array}$ & Total mortality & $\begin{array}{l}\text { Prospective } \\
\text { Follow-up of } \\
14 \text { years }\end{array}$ & $\begin{array}{l}41836 / 4653 \\
55-69 \text { years }\end{array}$ & FFQ of 127 items & $\begin{array}{l}\text { (1) Age and energy and } \\
\text { (2) covariates previously reported } \\
\text { to be associated with total and } \mathrm{CV} \\
\text { mortality in this cohort }\end{array}$ & $\begin{array}{l}1.21 \mathrm{v} .0 .96 \mathrm{~g} \mathrm{ALA} / \mathrm{d} \\
\text { (supplementary } \\
\text { analysis) }\end{array}$ & 0.85 (not given) & 0.01 \\
\hline $\begin{array}{l}\text { Albert et al.(90) } 2005 \\
\text { (NHS, USA) }\end{array}$ & SCD and other CHD & $\begin{array}{l}\text { Prospective } \\
\text { Follow-up of } \\
18 \text { years }\end{array}$ & $\begin{array}{l}76763 \text { women/206 } \\
\text { SCD, } 641 \text { other } \\
\text { CHD deaths } \\
30-55 \text { years }\end{array}$ & Validated FFQ & $\begin{array}{l}\text { Alcohol consumption, menopausal } \\
\text { status, HRT, PA, aspirin use, } \\
\text { vitamin supplements, hyper- } \\
\text { tension, hypercholesterolaemia, } \\
\text { diabetes, family history of MI and } \\
\text { history of prior CVD, trans-FA, } \\
\text { ratio of PUFA:SFA and } n-3 \mathrm{FA}\end{array}$ & $\begin{array}{l}0.74 \text { v. } 0.31 \% \text { TEI } \\
\text { as ALA }\end{array}$ & $\begin{array}{l}\text { SCD: } 0.60 \\
(0.37,0.96) \\
\text { Other outcomes: NS }\end{array}$ & 0.02 \\
\hline $\begin{array}{l}\text { Hu et al.(91) } 1999 \\
\text { (NHS, USA) }\end{array}$ & $\begin{array}{l}\text { Fatal and non-fatal } \\
\text { IHD }\end{array}$ & Prospective & $\begin{array}{l}76283 / 232 \text { fatal/597 } \\
\text { non-fatal IHD } \\
30-55 \text { years }\end{array}$ & FFQ of 116 items & $\begin{array}{l}\text { Age, BMI, smoking status, } \\
\text { hypertension, diabetes, hyper- } \\
\text { cholesterolaemia, menopausal } \\
\text { status, HRT, parental history of } \\
\text { MI, multiple vitamin use, alcohol } \\
\text { consumption, aspirin use, PA, } \\
\text { SFA, LA, vitamins C and E, } \\
\text { total energy }\end{array}$ & $1.36 \mathrm{v} .0 .31 \mathrm{~g} \mathrm{ALA} / \mathrm{d}$ & $\begin{array}{l}\text { Fatal IHD: } 0.55 \\
(0.32,0.94) \\
\text { Non-fatal IHD: NS }\end{array}$ & 0.01 \\
\hline $\begin{array}{l}\text { Lemaitre et al. }{ }^{(97)} \\
2012 \text { (Cardio- } \\
\text { vascular Health } \\
\text { Study) }\end{array}$ & $\begin{array}{l}\text { Fatal and non-fatal } \\
\text { IHD }\end{array}$ & $\begin{array}{l}\text { Prospective } \\
\text { Follow-up of } \\
10 \text { years } \\
\text { Pooled analysis of }\end{array}$ & $\begin{array}{l}\text { Dietary analyses } \\
4432 / 1072 \\
\text { Biomarkers } \\
2957 / 686\end{array}$ & $\begin{array}{l}\text { FFQ with pictures } \\
\text { Plasma } \\
\text { concentration }\end{array}$ & $\begin{array}{l}\text { Age, sex, race, education, smoking } \\
\text { status, BMI, waist circumference, } \\
\text { alcohol consumption }\end{array}$ & $\begin{array}{l}3.2 \text { v. } 1.41 \text { ALA as } \\
\% \text { total fat intake } \\
\% \text { Total plasma FA } \\
\text { concentration }\end{array}$ & $\begin{array}{l}\text { Dietary and } \\
\text { biomarker: NS }\end{array}$ & \\
\hline $\begin{array}{l}\text { Vedtofte et al. } \\
2014\end{array}$ & $\begin{array}{c}\text { Incident fatal and } \\
\text { non-fatal CHD }\end{array}$ & $\begin{array}{l}\text { eleven prospec- } \\
\text { tive cohorts } \\
\text { (criteria: } \geq 150 \\
\text { outcomes and } \\
\text { validated FFQ } \\
\text { or dietary record) } \\
\text { Follow-up of } \\
\quad 4-10 \text { years }\end{array}$ & $\begin{array}{l}229043 / 4493 \text { CHD } \\
\text { events and } 1751 \\
\text { CHD deaths }\end{array}$ & $\begin{array}{l}\text { FFQ or dietary } \\
\text { record }\end{array}$ & $\begin{array}{l}\text { BMI, education, smoking status, PA, } \\
\text { alcohol consumption, TEI, SFA, } \\
\text { trans-FA, MUFA, LA, } n-3 \text { LC- } \\
\text { PUFA, dietary fibre, hypertension }\end{array}$ & $\begin{array}{l}\text { Women: } 1.64 \mathrm{v} \text {. } \\
0.58 \mathrm{~g} \mathrm{ALA} / \mathrm{d} \\
\text { Men: } 1.62 \mathrm{v} .1 .17 \mathrm{~g} \\
\text { ALA/d }\end{array}$ & $\begin{array}{l}\text { Men: CHD event - } \\
\text { 0.85 (0.72, 1.01); } \\
\text { CHD death - } \\
\text { 0.77 (0.58, 1.01) } \\
\text { Women: CHD - NS; } \\
\text { CHD death - NS }\end{array}$ & $0.07 \dagger$ \\
\hline $\begin{array}{l}\text { Ascherio et al.(92) } \\
1996 \text { (HPFUS) }\end{array}$ & $\begin{array}{l}\text { Incidence of acute } \\
\text { MI or coronary } \\
\text { death }\end{array}$ & $\begin{array}{l}\text { Prospective } \\
\text { Follow-up of } 6 \text { years }\end{array}$ & $\begin{array}{l}\text { 3757/734 Ml/229 } \\
\text { deaths } \\
40-75 \text { years }\end{array}$ & $\begin{array}{l}\text { Validated FFQ of } \\
131 \text { items }\end{array}$ & $\begin{array}{l}\text { Age, BMI, smoking status, PA, } \\
\text { alcohol consumption, hyperten- } \\
\text { sion, cholesterol, family history of } \\
\text { MI, fibre intake, energy }\end{array}$ & $\begin{array}{l}1.5 \mathrm{v} .0 .8 \mathrm{~g} \mathrm{ALA} / \mathrm{d} \\
1 \% \text { energy } \\
\text { increase } / \mathrm{d}\end{array}$ & $\begin{array}{l}\text { MI: } 0.80(0.63 \text {, } \\
\text { 1.03); death: NS } \\
\text { MI: } 0.41(0.21 \\
0.80) \text {; death: NS }\end{array}$ & 0.07 \\
\hline $\begin{array}{l}\text { Mozaffarian et al. }{ }^{(93)} \\
2005\end{array}$ & $\mathrm{CHD}$ & $\begin{array}{l}\text { Prospective HPFUS } \\
\text { Follow-up of } \\
14 \text { years }\end{array}$ & $\begin{array}{l}45722 / 2306 \text { total } \\
\text { CHD/218 sudden } \\
\text { deaths } / 1521 \\
\text { non-fatal MI } \\
40-75 \text { years }\end{array}$ & $\begin{array}{l}\text { Validated FFQ of } \\
131 \text { items }\end{array}$ & $\begin{array}{l}\text { Age, BMI, smoking status, PA, } \\
\text { alcohol consumption, hyperten- } \\
\text { sion, cholesterol, family history of } \\
\text { MI, diabetes, aspirin use, protein, } \\
\text { SFA, fibre, MUFA, trans-FA, } \\
\text { energy, } n-6 \text { FA, EPA + DHA }\end{array}$ & $\begin{array}{c}1 \mathrm{~g} \mathrm{ALA} / \mathrm{d}+<100 \\
\mathrm{mg} E P A+\mathrm{DHA} \\
1 \mathrm{~g} \mathrm{ALA} / \mathrm{d}+\geq 100 \\
\mathrm{mg} E P A+D H A\end{array}$ & $\begin{array}{l}\text { Non-fatal MI: } 0.42 \\
\text { (0.23, 0.75) } \\
\text { Total CHD: } 0.53 \\
\text { (0.34, 0.83) } \\
\text { Death: NS } \\
\text { NS }\end{array}$ & \\
\hline $\begin{array}{l}\text { Lemaitre et al. } .^{(94)} \\
2003\end{array}$ & $\begin{array}{l}\text { Fatal and non-fatal } \\
\text { IHD }\end{array}$ & $\begin{array}{l}\text { Case-control } \\
\text { nested in the } \\
\text { Prospective } \\
\text { Cardiovascular } \\
\text { Health Study } \\
\text { Follow-up of } 3 \text { years }\end{array}$ & $\begin{array}{l}179 \text { controls } / 54 \text { fatal } \\
(58 \% \text { male)/ } \\
125 \text { non-fatal } \\
(64 \% \text { male }) \\
\geq 65 \text { years }\end{array}$ & $\begin{array}{l}\text { Plasma } \\
\text { measurements }\end{array}$ & $\begin{array}{l}\text { Age, study centre, sex, smoking } \\
\text { status, alcohol consumption, TAG, } \\
\text { HDL-cholesterol, hypertension, } \\
\text { diabetes, congestive heart failure, } \\
\text { claudication, heart rate, family } \\
\text { history of MI, fibrinogen, PA. } \\
\text { Analysis on combined PUFA }\end{array}$ & $\begin{array}{l}1 \text { SD increase } \\
\text { in plasma } \\
\text { concentration } \\
\text { of ALA }\end{array}$ & $\begin{array}{l}\text { Fatal and non-fatal } \\
\text { IHD: NS }\end{array}$ & \\
\hline
\end{tabular}


Table 3. Continued

\begin{tabular}{|c|c|c|c|c|c|c|c|c|}
\hline Study & $\begin{array}{l}\text { Disease } \\
\text { outcome }\end{array}$ & Study design & $\begin{array}{l}\text { Subjects/cases } \\
\text { and age range }\end{array}$ & $\begin{array}{l}\text { Exposure } \\
\text { measurement }\end{array}$ & Statistical adjustments & Intake categorisation & $\begin{array}{l}\text { Relative } \\
\text { risk }^{\star}(95 \% \mathrm{Cl})\end{array}$ & Trend \\
\hline $\begin{array}{l}\text { Pietinen et al. } .^{(95)} \\
1997 \text { (ATBC } \\
\text { cohort, Finland) }\end{array}$ & $\mathrm{CHD}$ & $\begin{array}{l}\text { Prospective } \\
\text { Follow-up of } 6 \text { years }\end{array}$ & $\begin{array}{l}21930 / 1399 \\
\text { events/633 } \\
\text { deaths }\end{array}$ & $\begin{array}{l}\text { Validated FFQ of } \\
276 \text { items }\end{array}$ & $\begin{array}{l}\text { Age, supplement, group, several } \\
\text { coronary risk factors, total energy } \\
\text { and fibre intake }\end{array}$ & $2.5 \mathrm{v} .0 .9 \mathrm{~g} \mathrm{ALA} / \mathrm{d}$ & NS & \\
\hline $\begin{array}{l}\text { Oomen et al. }{ }^{(96)} \\
2001 \text { (Zutphen } \\
\text { Elderly Cohort) }\end{array}$ & $\begin{array}{l}\text { Coronary artery } \\
\text { disease }\end{array}$ & Prospective & $667 / 98$ & $\begin{array}{l}\text { Cross-check, dietary } \\
\text { history method }\end{array}$ & $\begin{array}{l}\text { Age, standard coronary risk factors, } \\
\text { intake of trans-FA and other } \\
\text { nutrients }\end{array}$ & $\begin{array}{l}\geq 0.58 v .<0.45 \\
\text { ALA as \% energy } \\
\text { intake }\end{array}$ & NS & \\
\hline $\begin{array}{l}\text { Wilk et al. }{ }^{(100)} 2012 \\
\quad \text { (Physician's } \\
\text { Health Study) }\end{array}$ & Heart failure & $\begin{array}{l}\text { Prospective, nested } \\
\text { case-control }\end{array}$ & $19097 / 1572$ & $\begin{array}{l}\text { Plasma measure- } \\
\text { ments and } \\
\text { validated FFQ }\end{array}$ & $\begin{array}{l}\text { Age at the time of blood sampling, } \\
\text { atrial fibrillation, hypertension, } \\
\text { BMI, alcohol consumption, } \\
\text { smoking status }\end{array}$ & $\begin{array}{l}\text { Plasma ALA con- } \\
\text { centration: } 0.306 \\
v .0 .097 \text { as } \% \\
\text { total FA. Dietary } \\
\text { ALA: } v .0 .576 \mathrm{~g} / \mathrm{d}\end{array}$ & $\begin{array}{l}\text { Plasma Q4: } 0.66 \\
\text { (0.47, 0.94); } \\
\text { Q5: NS; Dietary: } \\
\text { NS }\end{array}$ & \\
\hline $\begin{array}{l}\text { Fretts et al. }{ }^{(101)} \\
2013 \\
\text { (Cardiovascular } \\
\text { Health Study, } \\
\text { USA) }\end{array}$ & $\begin{array}{l}\text { Incident atrial } \\
\text { fibrillation }\end{array}$ & Prospective & $\begin{array}{l}4337 \\
\geq 65 \text { years }\end{array}$ & $\begin{array}{l}\text { Plasma measure- } \\
\text { ments and } \\
\text { validated FFQ, } \\
131 \text { items }\end{array}$ & $\begin{array}{l}\text { Age, sex (and total energy intake for } \\
\text { dietary analyses), race, education, } \\
\text { smoking status, history of heart } \\
\text { failure, history of stroke, BMI, } \\
\text { waist circumference, PA, } \\
\text { hypertension, LA (for plasma } \\
\text { measurements) }\end{array}$ & $\begin{array}{l}0.21 \text { v. } 0.10 \text { as } \% \\
\text { total FA }\end{array}$ & $\begin{array}{l}\text { Plasma: NS } \\
\text { Dietary: NS }\end{array}$ & $\begin{array}{l}\text { NS } \\
\text { NS }\end{array}$ \\
\hline $\begin{array}{l}\text { Pelser et al.(107) } \\
2013 \text { (NIH-AARP, } \\
\text { USA) }\end{array}$ & Prostate cancer & $\begin{array}{l}\text { Prospective } \\
\text { Follow-up of } 9 \text { years }\end{array}$ & $\begin{array}{l}288268 / 23281 \\
\quad(18934 \text { non- } \\
\text { advanced/2930 } \\
\text { advanced/725 } \\
\text { fatal) } \\
50-71 \text { years }\end{array}$ & $\begin{array}{l}\text { Validated FFQ of } \\
124 \text { items }\end{array}$ & $\begin{array}{l}\text { Age, race, family history, marital } \\
\text { status, education, diabetes, PSA } \\
\text { screening, total energy, alcohol } \\
\text { consumption, tomatoes, BMI in } \\
\text { three levels }(<25,25-<30 \text { and } \\
\left.\geq 30 \mathrm{~kg} / \mathrm{m}^{2}\right), \text { PA, smoking status }\end{array}$ & $\begin{array}{c}0.41 \text { v. } 0.88 \text { as } \\
\% \text { energy }\end{array}$ & $\begin{array}{cc}\text { Non-advanced: NS } \\
\text { Advanced: } & 1.17 \\
(1.04,1.3) & \end{array}$ & 0.01 \\
\hline $\begin{array}{c}\text { Chajes et all.(108) } \\
2011 \text { (EPIC) }\end{array}$ & $\begin{array}{l}\text { Gastric } \\
\quad \text { adenocarcinoma }\end{array}$ & $\begin{array}{l}\text { Prospective } \\
\text { Nested in the cohort }\end{array}$ & $\begin{array}{l}626 / 238 \\
43-72 \text { years }\end{array}$ & $\begin{array}{l}\text { Plasma } \\
\text { concentration }\end{array}$ & $\begin{array}{l}\text { Helicobacter pylori infection, BMI, } \\
\text { smoking status, PA, education, } \\
\text { socio-economic status, energy } \\
\text { intake }\end{array}$ & $\begin{array}{l}\geq 0.24 v .<0.13 \\
\text { ALA as \% total } \\
\text { FA }\end{array}$ & $3.20(1.70,6.06)$ & 0.001 \\
\hline
\end{tabular}
CV, cardiovascular; NHS, Nurse's Health Study; SCD, sudden cardiac death; HRT, hormone replacement therapy; PA, physical activity; MI, myocardial infarction; FA, fatty acids; TEI, total energy intake; LA, linoleic acid; LC, long
chain; HPFUS, Health Professional Follow-up Study; Q, quintile; NIH-AARP National Institute of Health Aged American Retired Persons; PSA, prostate-specific antigen; EPIC, European Prospective Investigation into Cancer and Nutrition.

"When used as a nested case-control study.

$\dagger P$ for sex interaction 
and oleuropein reduced $\beta$-amyloid levels and plaque deposits $^{(79,80)}$, and improved memory ${ }^{(81)}$.

The severity of skin photo-ageing was significantly attenuated by the consumption of MUFA from $\mathrm{OO}$ in subjects of the Suppléments en Vitamines et Minéraux Antioxydants (SUVIMAX) cohort $^{(82)}$. Only MUFA from OO was efficient, suggesting that phenolic compounds or squalene in OO might be responsible for the beneficial effect on skin photo-ageing

In summary, based on the recognised criteria of evidence in human studies, the level of evidence for the relationship of EVOO with CVD can be qualified as 'convincing', and for cancers as 'limited-suggestive', especially ER - breast cancer. For ageing and cognitive impairment, fewer data exist in favour of a specific beneficial effect of $O O$, and require confirmation. There is good evidence from both human and experimental studies that phenolic compounds present in EVOO are important for cardiovascular benefits. More limited experimental studies have also suggested that phenolic compounds are important for the anti-cancer and neuroprotective effects of EVOO.

Rapeseed oil and health. Whereas many studies have examined the relationship of OO with disease incidence or mortality as well as biomarkers for disease, studies with RO are mainly limited to outcomes based on biomarkers. Funding from the food industry and the RO industry was received by two recent reviews ${ }^{(83,84)}$, hence leading to possible conflicts of interest ${ }^{(85,86)}$. Most studies with RO have used raw RO. This limits the interpretation of these studies since most $\mathrm{RO}$ is consumed after frying, and this can cause significant changes in composition, especially of ALA, as discussed previously.

$C V D$. A number of reports comparing the effect of $\mathrm{RO}$ with a source of SFA on the biomarkers of CVD risk (total cholesterol, LDL-cholesterol, HDL-cholesterol and TAG, lipid peroxidation and inflammatory biomarkers) have found that $\mathrm{RO}$ is relatively beneficial, as it is an oil low in SFA and high in MUFA + PUFA $^{(84)}$. As the US Food and Drug Administration put it in the qualified health claim for RO in 2006: 'Limited and not conclusive scientific evidence suggests that eating about 1.5 tablespoons $(19 \mathrm{~g})$ of $\mathrm{RO}$ daily may reduce the risk of $\mathrm{CHD}$ due to the unsaturated fat content in RO. To achieve this possible benefit, $\mathrm{RO}$ is to replace a similar amount of saturated fat and not increase the total number of calories you eat in a day. ${ }^{\text {(87) }}$

It is the generally accepted view that the benefits to heart health are greater when SFA is replaced with PUFA, rather than when SFA is substituted with MUFA ${ }^{(50)}$. Since there are no observational studies with $\mathrm{RO}$, a review of epidemiological studies of the specific effect of ALA is relevant, albeit with the proviso of possible changes due to frying. These are summarised in Table 3. A review by the Afssa expert group in 2008 concluded that results on mortality were inconsistent ${ }^{(88)}$. Whereas Folsom \& Demissie ${ }^{(89)}$ observed a modest risk reduction of total mortality in the Iowa Women's Health Study, two studies from the Nurse's Health Study cohort found an effect on mortality only from a sudden cardiac event $^{(90,91)}$. Similarly, two studies ${ }^{(92,93)}$ from the Health Professional Study showed a risk reduction in myocardial infarction. An interesting finding was the observation that there was a risk reduction by ALA when EPA + DHA consumption was $<100 \mathrm{mg} / \mathrm{d}$, and that this effect was lost when $\mathrm{EPA}+$ DHA consumption was $\geq 100 \mathrm{mg} / \mathrm{d}$ with a significant interaction $(P=0.003$ for myocardial infarction and $P=0.006$ for total $C V D$ ) between the two intakes. Similarly, the risk reduction observed for fatal IHD in a prospective study based on the measurement of ALA in phospholipids was abolished after adjusting for $\mathrm{EPA}+\mathrm{DHA}^{(94)}$. In two prospective studies based on ALA intake and conducted in Northern Europe, the Alpha-Tocopherol, Beta-Carotene (ATBC) study $^{(95)}$ and the Zutphen study ${ }^{(96)}$, no significant association has been observed.

More recently, another study based on circulating and dietary ALA found no effect of this FA on congestive heart failure ${ }^{(97)}$. In a meta-analysis published in 2012, there was a borderline significant risk reduction for CVD, and only fatal CHD was significant ${ }^{(98)}$. A large unexplained heterogeneity was present in this meta-analysis, casting doubts on the results. A more recent analysis using a pooled study design found a nonsignificant inverse association between ALA intake and CHD risk in men, but found no consistent association in women ${ }^{(99)}$. There has also been a report of a moderate non-linear association between ALA and heart failure ${ }^{(100)}$, and another showing no association of ALA with atrial fibrillation ${ }^{(101)}$.

Several studies have compared the effect of RO with that of OO on risk factors for CVD. A hypoenergetic RO-containing diet (supplied as oil and margarine) reduced systolic blood pressure, and total and LDL-cholesterol to a comparable extent as a refined $\mathrm{OO}$ diet, and also resulted in a greater reduction in diastolic blood pressure, probably because of the higher ALA content of the RO diet ${ }^{(102)}$. In another study, $\mathrm{RO}$ resulted in a reduction of total cholesterol of $12 v .5 \cdot 4 \%$ for OO, but HDL-cholesterol was also significantly reduced in the RO group, but not in the OO group ${ }^{(103)}$. In a further study, eighteen subjects in six experimental cross-over groups received $50 \mathrm{~g}$ oil $/ 10 \mathrm{MJ}$ in a diet of $15 \mathrm{MJ}$. After 3 weeks, there was a significant reduction of LDL-cholesterol in the RO group, which is expected since RO contains $21 \%$ PUFA $^{(104)}$. All other biomarkers were not significantly different. With the same study design, the same group later published the results on TAG. After 3 weeks, fasting TAG concentrations were significantly higher for the OO regimen, with no difference on either postprandial TAG or susceptibility to lipoprotein oxidation ${ }^{(105)}$.

In conclusion, despite limited evidence of the beneficial effects of RO in short-term studies on the biomarkers of risk factors for CVD, there are currently no observational and intervention studies to suggest that RO has the cardiovascular benefits of EVOO. Any benefits of RO are likely to be due to ALA.

Cancer. ALA has been associated with an increased risk of prostate cancer, but results have been inconsistent. A meta-analysis did not find an association between dietary ALA intake and prostate cancer risk $^{(106)}$, although a more recent study has found that ALA intake increased the risk of advanced prostate cancer in elderly men ${ }^{(107)}$ (Table 3). There are indications of risk for gastric cancer ${ }^{(108)}$. Inhalation 
of the vapours from unrefined $\mathrm{RO}$ with a high content of ALA used for cooking was associated with cancers in China ${ }^{(109)}$.

We did not conduct searches for the effects of RO on other diseases.

\section{Discussion}

\section{Recent developments}

The increased susceptibility of ALA to oxidation has led to the commercial development of modified RO with decreased ALA. These include a low-linolenic acid RO, which has increased linoleic acid content, and high-oleic acid $\mathrm{RO}^{(15)}$. These modified oils have better heat stability ${ }^{(37)}$, but they are more expensive than the standard RO. Currently, there are no clinical studies on their effects on health. However, as noted above, reducing ALA and increasing MUFA may reduce the possible cardioprotective benefits of $\mathrm{RO}$.

A second approach has been to increase the level of antioxidant phytochemicals in RO. In 2006, the European Union-funded project 'Optim'Oils' was initiated with the aim of improving production methods for $\mathrm{RO}$. An oil with significantly lower 18:3 trans and improved phytochemical composition (minimised losses of phytosterols, tocopherols and phenolics) was successfully developed ${ }^{(17)}$. In a clinical study, total/HDL-cholesterol and LDL/HDL-cholesterol concentrations were increased by $4 \%(P<0.05)$ with the consumption of raw standard $\mathrm{RO}$, and there were also nonsignificant increases in oxidised LDL. These increases were not observed with the optimised oil ${ }^{(110)}$, and hence there were modest benefits of the optimised RO compared with the standard RO.

Another interesting way forward is to incorporate olive phenolics into $\mathrm{RO}$. The waste water from $\mathrm{OO}$ production (olive mill waste water, OMWW) contains high levels of some olive phenolics ${ }^{(111)}$, and disposal of OMWW is of major environmental concern ${ }^{(112)}$. An OMWW extract has been used to improve the oxidative stabilities of $\operatorname{lard}^{(113)}$, sunflower oil ${ }^{(114)}$ and refined $\mathrm{OO}^{(115)}$. A seed oil comprising $30 \%$ high-oleic sunflower oil and $70 \%$ RO enriched with OMWW was found to reduce postprandial inflammation in obese subjects as effectively as VOO, even after twenty cycles of heating the oils at $180^{\circ} \mathrm{C}^{(34)}$. Incorporation of phenolic compounds from OMWW also has the potential to improve the cardiovascular health benefits of RO since OMWW, which has high levels of hydroxytyrosol, has been shown to reduce LDL oxidation ${ }^{(116)}$.

\section{Conclusions}

The extensive evidence for the health benefits of EVOO is not matched by similar data for $\mathrm{RO}$, and based on current evidence, RO cannot be recommended as equivalent in terms of health benefits compared with EVOO. There are significant losses of minor constituents during the processing of standard RO, and there may also be deleterious changes in FA composition when $\mathrm{RO}$ is used for cooking. New initiatives to alter the production methods and composition of RO are addressing some of these issues and could lead to a far healthier, albeit more expensive, product for the consumer in the future. Nevertheless, RO lacks many of the constituents in EVOO, such as secoiridoids and their derivatives, which are thought to be important for its health benefits and desirable stability during cooking. The use of OMWW to stabilise RO and improve its health benefits may be of mutual benefit to both industries by using an environmentally polluting waste product from the $\mathrm{OO}$ industry to the benefit of producing a healthier product for the RO industry. However, the current high fungicide usage on the oilseed rape crop is also of concern ${ }^{(117)}$.

\section{Acknowledgements}

The present review received no specific grant from any funding agency in the public, commercial or not-for-profit sectors.

The authors' contributions were as follows: M. G. was responsible for the Health sections; R. H. conceived the article and was responsible for the remainder of the content and editing of the article.

Neither of the authors has any conflicts of interest to declare.

\section{References}

1. Sofi F, Abbate R, Gensini GF, et al. (2011) Accruing evidence on benefits of adherence to the Mediterranean diet on health: an updated systematic review and meta-analysis. Am J Clin Nutr 92, 1189-1196.

2. National Institute for Health and Care Excellence (2013) Secondary prevention in primary and secondary care for patients following a myocardial infarction. NICE Clinical Guideline 172.

3. Piscopo S (2009) The Mediterranean diet as a nutrition education, health promotion and disease prevention tool. Public Health Nutr 12, 1648-1655.

4. NHS Choices (2014) The eatwell plate. http://www.nhs.uk/ Livewell/Goodfood/Pages/eatwell-plate.aspx (accessed 5 February 2014).

5. Bere E \& Brug J (2009) Towards health-promoting and environmentally friendly regional diets - a Nordic example. Public Health Nutr 12, 91-96.

6. Logan KJ, Woodside JV, Young IS, et al. (2010) Adoption and maintenance of a Mediterranean diet in patients with coronary heart disease from a Northern European population: a pilot randomised trial of different methods of delivering Mediterranean diet advice. J Hum Nutr Diet 23, 30-37.

7. Papadaki A \& Scott JA (2008) Follow-up of a web-based tailored intervention promoting the Mediterranean diet in Scotland. Patient Educ Couns 73, 256-263.

8. Hoffman R \& Gerber M (2013) Evaluating and adapting the Mediterranean diet for non-Mediterranean populations: a critical appraisal. Nutr Rev 71, 573-584.

9. Bere E \& Brug J (2010) Is the term 'Mediterranean diet' a misnomer? Public Health Nutr 13, 2127-2129.

10. Lopez-Miranda J, Perez-Jimenez F, Ros E, et al. (2010) Olive oil and health: summary of the II international conference on olive oil and health consensus report, Jaen and Cordoba (Spain) 2008. Nutr Metab Cardiovasc Dis 20, 284-294. 
11. Linseisen J, Welch AA, Ocke M, et al. (2009) Dietary fat intake in the European Prospective Investigation into Cancer and Nutrition: results from the 24-h dietary recalls. Eur J Clin Nutr 63, Suppl. 4, S61-S80.

12. Bermudez B, Lopez S, Ortega A, et al. (2011) Oleic acid in olive oil: from a metabolic framework toward a clinical perspective. Curr Pharm Des 17, 831-843.

13. Cicerale S, Conlan XA, Sinclair AJ, et al. (2009) Chemistry and health of olive oil phenolics. Crit Rev Food Sci Nutr 49, 218-236

14. MailOnline (2013) Rapeseed oil sales soar as middle class cooks turn to it instead of olive oil because it has half the amount of saturated fat. http://www.dailymail.co.uk/ news/article-2335289/ (accessed 5 February 2014).

15. Przybylski R (2011) Canola/rapeseed oil. In Vegetable Oils in Food Technology: Composition, Properties and Uses, 2nd ed., pp. 107-136 [FD Gunstone, editor]. Oxford: Wiley-Blackwell.

16. Boskou D (2011) Olive oil. In Vegetable Oils in Food Technology: Composition, Properties and Uses, 2nd ed., pp. 243-271 [FD Gunstone, editor]. Oxford: Wiley-Blackwell.

17. Gladine C, Meunier N, Blot A, et al. (2011) Preservation of micronutrients during rapeseed oil refining: a tool to optimize the health value of edible vegetable oils? Rationale and design of the Optim'Oils randomized clinical trial. Contemp Clin Trials 32, 233-239.

18. Vermunt SH, Beaufrere B, Riemersma RA, et al. (2001) Dietary trans $\alpha$-linolenic acid from deodorised rapeseed oil and plasma lipids and lipoproteins in healthy men: the TransLinE Study. Br J Nutr 85, 387-392.

19. Bendsen NT, Christensen R, Bartels EM, et al. (2011) Consumption of industrial and ruminant trans fatty acids and risk of coronary heart disease: a systematic review and meta-analysis of cohort studies. Eur J Clin Nutr 65, $773-783$.

20. HGCA, Agriculture and Horticulture Development Board (2014) Rapeseed Oil Benefits a Healthy Choice. http://rape seedoilbenefits.hgca.com/guide-to-rapeseed-oil/rapeseedoil-health-benefits.aspx (accessed 5 February 2014).

21. Levy LB (2013) Dietary strategies, policy and cardiovascular disease risk reduction in England. Proc Nutr Soc $\mathbf{7 2}$, 386-389.

22. Servili M, Sordini B, Esposto S, et al. (2014) Biological activities of phenolic compounds of extra virgin olive oil. Antioxidants 3, 1-23.

23. Cicerale S, Lucas L \& Keast R (2010) Biological activities of phenolic compounds present in virgin olive oil. Int J Mol Sci 11, 458-479.

24. Warleta F, Campos M, Allouche Y, et al. (2010) Squalene protects against oxidative DNA damage in MCF10A human mammary epithelial cells but not in MCF7 and MDA-MB-231 human breast cancer cells. Food Chem Toxicol 48, 1092-1100.

25. Landete JM (2012) Plant and mammalian lignans: a review of source, intake, metabolism, intestinal bacteria and health. Food Res Int 46, 410-424.

26. Tresserra-Rimbau A, Medina-Remon A, Perez-Jimenez J, et al. (2013) Dietary intake and major food sources of polyphenols in a Spanish population at high cardiovascular risk: the PREDIMED study. Nutr Metab Cardiovasc Dis $\mathbf{2 3}$, 953-959.

27. Zacchi P \& Eggers R (2008) High-temperature preconditioning of rapeseed: a polyphenol-enriched oil and the effect of refining. Eur J Lipid Sci Technol 110, 111-119.
28. Frankel EN (2005) Lipid Oxidation, 2nd ed. Bridgwater: Oily Press.

29. Roe M, Pinchen H, Church S, et al. (2013) Trans fatty acids in a range of UK processed foods. Food Chem 140, 427-431.

30. Roman O, Heyd B, Broyart B, et al. (2013) Oxidative reactivity of unsaturated fatty acids from sunflower, high oleic sunflower and rapeseed oils subjected to heat treatment, under controlled conditions. Food Sci Technol 52, 49-59.

31. Santos CSP, Cruz R, Cunha SC, et al. (2013) Effect of cooking on olive oil quality attributes. Food Res Int 54, 2016-2024.

32. Sacchi R, Paduano A, Savarese M, et al. (2014) Extra virgin olive oil: from composition to "molecular gastronomy". Cancer Treat Res 159, 325-338.

33. Gomez-Alonso S, Fregapane G, Salvador MD, et al. (2003) Changes in phenolic composition and antioxidant activity of virgin olive oil during frying. J Agric Food Chem 51, 667-672.

34. Perez-Herrera A, Delgado-Lista J, Torres-Sanchez LA, et al. (2012) The postprandial inflammatory response after ingestion of heated oils in obese persons is reduced by the presence of phenol compounds. Mol Nutr Food Res 56, $510-514$

35. Chiou A, Kalogeropoulos N, Boskou G, et al. (2012) Migration of health promoting microconstituents from frying vegetable oils to French fries. Food Chem 133, 1255-1263.

36. Kalogeropoulos N, Chiou A, Mylona A, et al. (2007) Recovery and distribution of natural antioxidants ( $\alpha$-tocopherol, polyphenols and terpenic acids) after pan-frying of Mediterranean finfish in virgin olive oil. Food Chem 100, 509-517.

37. Przybylski R, Gruczynska E \& Aladedunye F (2013) Performance of regular and modified canola and soybean oils in rotational frying. J Am Oil Chem Soc 90, 1271-1280.

38. Warner K \& Mounts TL (1993) Frying stability of soybean and canola oils with modified fatty acid composition. $J \mathrm{Am}$ Oil Chem Soc 70, 983-988.

39. Moya Moreno MCM, Mendoza Olivares D, Amezquita Lopez FJ, et al. (1999) Analytical evaluation of polyunsaturated fatty acids degradation during thermal oxidation of edible oils by Fourier transform infrared spectroscopy. Talanta 50, 269-275.

40. European Commission (2007) Recommendation from the Scientific Committee on Occupational Exposure Limits for acrolein. SCOEL/SUM/32. ec.europa.eu/social/BlobServlet? docId $=6862 \&$ langId $=$ en

41. Fullana A, Carbonell-Barrachina AA \& Sidhu S (2004) Comparison of volatile aldehydes present in the cooking fumes of extra virgin olive, olive, and canola oils. J Agric Food Chem 52, 5207-5214.

42. Katragadda HR, Fullana A, Sidhu S, et al. (2010) Emissions of volatile aldehydes from heated cooking oils. Food Chem 120, 59-65.

43. Ewert A, Granvogl M \& Schieberle P (2012) Comparative studies on the generation of acrolein as well as of aromaactive compounds during deep-frying with different edible vegetable fats and oils. In ACS Symposium Series. Recent Advances in the Analysis of Food and Flavors, pp. 129-136. Washington, DC: American Chemical Society vol. 1098.

44. Endo Y, Chieko C, Yamanaka T, et al. (2013) Linolenic acid as the main source of acrolein formed during heating of vegetable oils. J Am Oil Chem Soc 90, 959-964.

45. Procida G, Cichelli A, Compagnone D, et al. (2009) Influence of chemical composition of olive oil on the 
development of volatile compounds during frying. Eur Food Res Technol 230, 217-229.

46. WHO (2013) Diet, Nutrition and the Prevention of Chronic Diseases. World Health Organization Technical Report Series no. 0512-3054 (Print) 0512-3054 (Linking). Geneva: WHO.

47. World Cancer Research Fund/American Institute for Cancer Research (2007) Food, Nutrition, Physical Activity, and the Prevention of Cancer: a Global Perspective. Washington, DC: AICR

48. Hoffman R \& Gerber M (2012) The Mediterranean Diet: Health \& Science. Oxford: Wiley-Blackwell.

49. Keys A, Menotti A, Aravanis C, et al. (1984) The seven countries study: 2,289 deaths in 15 years. Prev Med 13, 141-154.

50. Jakobsen MU, O'Reilly EJ, Heitmann BL, et al. (2009) Major types of dietary fat and risk of coronary heart disease: a pooled analysis of 11 cohort studies. Am J Clin Nutr 89, 1425-1432.

51. Samieri C, Feart C, Proust-Lima C, et al. (2011) Olive oil consumption, plasma oleic acid, and stroke incidence: the Three-City Study. Neurology 77, 418-425.

52. Bendinelli B, Masala G, Saieva C, et al. (2011) Fruit, vegetables, and olive oil and risk of coronary heart disease in Italian women: the EPICOR Study. Am J Clin Nutr 93, 275-283.

53. Buckland G, Mayen AL, Agudo A, et al. (2012) Olive oil intake and mortality within the Spanish population (EPIC-Spain). Am J Clin Nutr 96, 142-149.

54. Martinez-Gonzalez MA, Dominguez LJ \& DelgadoRodriguez M (2014) Olive oil consumption and risk of CHD and/or stroke: a meta-analysis of case-control, cohort and intervention studies. Br J Nutr 112, 248-259.

55. Buckland G, Travier N, Barricarte A, et al. (2012) Olive oil intake and $\mathrm{CHD}$ in the European Prospective Investigation into Cancer and Nutrition Spanish cohort. Br J Nutr 108, 2075-2082.

56. Estruch R, Ros E, Salas-Salvado J, et al. (2013) Primary prevention of cardiovascular disease with a Mediterranean diet. $N$ Engl J Med 368, 1279-1290.

57. Guasch-Ferré M, Hu FB, Martinez-Gonzalez MA, et al. (2014) Olive oil intake and risk of cardiovascular disease and mortality in the PREDIMED Study. BMC Med 12, $78-89$.

58. Covas MI, Nyyssonen K, Poulsen HE, et al. (2006) The effect of polyphenols in olive oil on heart disease risk factors: a randomized trial. Ann Intern Med 145, 333-341.

59. EFSA (2011) Scientific Opinion on the substantiation of health claims related to polyphenols in olive and protection of LDL particles from oxidative damage (ID 1333, 1638, 1639, 1696, 2865), maintenance of normal blood HDL cholesterol concentrations (ID 1639), maintenance of normal blood pressure (ID 3781), "anti-inflammatory properties" (ID 1882), "contributes to the upper respiratory tract health" (ID 3468), "can help to maintain a normal function of gastrointestinal tract" (3779), and "contributes to body defences against external agents" (ID 3467) pursuant to Article 13(1) of Regulation (EC) No. 1924/ 2006. EFSA J 9, 2033-2057.

60. Urpi-Sarda M, Casas R, Chiva-Blanch G, et al. (2012) Virgin olive oil and nuts as key foods of the Mediterranean diet effects on inflammatory biomarkers related to atherosclerosis. Pharmacol Res 65, 577-583.

61. Lou-Bonafonte JM, Arnal C, Navarro MA, et al. (2012) Efficacy of bioactive compounds from extra virgin olive oil to modulate atherosclerosis development. Mol Nutr Food Res 56, 1043-1057.

62. Lucas L, Russell A \& Keast R (2011) Molecular mechanisms of inflammation. Anti-inflammatory benefits of virgin olive oil and the phenolic compound oleocanthal. Curr Pharm Des 17, 754-768.

63. Carluccio MA, Siculella L, Ancora MA, et al. (2003) Olive oil and red wine antioxidant polyphenols inhibit endothelial activation: antiatherogenic properties of Mediterranean diet phytochemicals. Arterioscler Thromb Vasc Biol 23 622-629.

64. Delgado-Lista J, Garcia-Rios A, Perez-Martinez P, et al (2011) Olive oil and haemostasis: platelet function, thrombogenesis and fibrinolysis. Curr Pharm Des 17, 778-785.

65. Gillingham LG, Harris-Janz S \& Jones PJ (2011) Dietary monounsaturated fatty acids are protective against metabolic syndrome and cardiovascular disease risk factors. Lipids 46, 209-228.

66. Teres S, Barcelo-Coblijn G, Benet M, et al. (2008) Oleic acid content is responsible for the reduction in blood pressure induced by olive oil. Proc Natl Acad Sci U A 105, 13811-13816.

67. Casaburi I, Puoci F, Chimento A, et al. (2013) Potential of olive oil phenols as chemopreventive and therapeutic agents against cancer: a review of in vitro studies. $\mathrm{Mol}$ Nutr Food Res 57, 71-83.

68. Pelucchi C, Bosetti C, Negri E, et al. (2011) Olive oil and cancer risk: an update of epidemiological findings through 2010. Curr Pharm Des 17, 805-812.

69. Bessaoud F, Daures JP \& Gerber M (2008) Dietary factors and breast cancer risk: a case control study among a population in Southern France. Nutr Cancer 60, 177-187.

70. Cottet V, Touvier M, Fournier A, et al. (2009) Postmenopausal breast cancer risk and dietary patterns in the E3N-EPIC prospective cohort study. Am J Epidemiol 170, 1257-1267.

71. Siari S, Scali J, Richard A, et al. (2002) Subregional variations of dietary consumption and incidences of cancers in southern France. IARC Sci Publ 156, 127-129.

72. Buckland G, Travier N, Agudo A, et al. (2012) Olive oil intake and breast cancer risk in the Mediterranean countries of the European Prospective Investigation into Cancer and Nutrition study. Int J Cancer 131, 2465-2469.

73. Elamin MH, Daghestani MH, Omer SA, et al. (2013) Olive oil oleuropein has anti-breast cancer properties with higher efficiency on ER-negative cells. Food Chem Toxicol 53, 310-316.

74. Berr C, Portet F, Carriere I, et al. (2009) Olive oil and cognition: results from the Three-City Study. Dement Geriatr Cogn Disord 28, 357-364.

75. Valls-Pedret C, Lamuela-Raventos RM, Medina-Remon A, et al. (2012) Polyphenol-rich foods in the Mediterranean diet are associated with better cognitive function in elderly subjects at high cardiovascular risk. J Alzheimers Dis 29, $773-782$.

76. Martínez-Lapiscina EH, Clavero P, Toledo E, et al. (2013) Virgin olive oil supplementation and long-term cognition: the PREDIMED-NAVARRA randomized, trial. $J$ Nutr Health Aging 17, 544-552.

77. Gorelick PB (2010) Role of inflammation in cognitive impairment: results of observational epidemiological studies and clinical trials. Ann N Y Acad Sci 1207, 155-162.

78. St-Laurent-Thibault C, Arseneault M, Longpre F, et al. (2011) Tyrosol and hydroxytyrosol, two main components of olive oil, protect N2a cells against amyloid- $\beta$-induced toxicity. Involvement of the NF-kB signaling. Curr Alzheimer Res 8, 543-551. 
79. Grossi C, Rigacci S, Ambrosini S, et al. (2013) The polyphenol oleuropein aglycone protects TgCRND8 mice against Ass plaque pathology. PLOS ONE 8, e71702.

80. Abuznait AH, Qosa H, Busnena BA, et al. (2013) Olive-oilderived oleocanthal enhances $\beta$-amyloid clearance as a potential neuroprotective mechanism against Alzheimer's disease: in vitro and in vivo studies. ACS Chem Neurosci 4, 973-982.

81. Farr SA, Price TO, Dominguez LJ, et al. (2012) Extra virgin olive oil improves learning and memory in SAMP8 mice. $J$ Alzheimers Dis 28, 81-92.

82. Latreille J, Kesse-Guyot E, Malvy D, et al. (2012) Dietary monounsaturated fatty acids intake and risk of skin photoaging. PLOS ONE 7, e44490.

83. Harland JI (2009) An assessment of the economic and heart health benefits of replacing saturated fat in the diet with monounsaturates in the form of rapeseed (canola) oil. Nutr Bull 34, 174-184.

84. Lin L, Allemekinders H, Dansby A, et al. (2013) Evidence of health benefits of canola oil. Nutr Rev 71, 370-385.

85. Bes-Rastrollo M, Schulze MB, Ruiz-Canela M, et al. (2013) Financial conflicts of interest and reporting bias regarding the association between sugar-sweetened beverages and weight gain: a systematic review of systematic reviews. PLoS Med 10, e1001578, discussion e1001578.

86. Smith R (2006) Conflicts of interest: how money clouds objectivity. J R Soc Med 99, 292-297.

87. Center for Food Safety and Applied Nutrition Qualified Health Claims - Qualified Health Claims: Letter of Enforcement Discretion - Unsaturated Fatty Acids from Canola Oil and Reduced Risk of Coronary Heart Disease (Docket No. 2006Q-0091)

88. Anses (2011) Actualisation des apports nutritionnels conseillés pour les acides gras. Rapport d'expertise collective (Updating recommended dietary intakes for fatty acids. Collective expert report). pmb.santenpdc.org/opac_css/ doc_num.php?explnum_id=11878

89. Folsom AR \& Demissie Z (2004) Fish intake, marine omega3 fatty acids, and mortality in a cohort of postmenopausal women. Am J Epidemiol 160, 1005-1010.

90. Albert CM, Oh K, Whang W, et al. (2005) Dietary $\alpha$-linolenic acid intake and risk of sudden cardiac death and coronary heart disease. Circulation 112, 3232-3238.

91. Hu FB, Stampfer MJ, Manson JE, et al. (1999) Dietary intake of $\alpha$-linolenic acid and risk of fatal ischemic heart disease among women. Am J Clin Nutr 69, 890-897.

92. Ascherio A, Rimm EB, Giovannucci EL, et al. (1996) Dietary fat and risk of coronary heart disease in men: cohort follow up study in the United States. BMJ 313, 84-90.

93. Mozaffarian D, Ascherio A, Hu FB, et al. (2005) Interplay between different polyunsaturated fatty acids and risk of coronary heart disease in men. Circulation 111, 157-164.

94. Lemaitre RN, King IB, Mozaffarian D, et al. (2003) n-3 Polyunsaturated fatty acids, fatal ischemic heart disease, and nonfatal myocardial infarction in older adults: the Cardiovascular Health Study. Am J Clin Nutr 77, 319-325.

95. Pietinen P, Ascherio A, Korhonen P, et al. (1997) Intake of fatty acids and risk of coronary heart disease in a cohort of Finnish men. The Alpha-Tocopherol, Beta-Carotene Cancer Prevention Study. Am J Epidemiol 145, 876-887.

96. Oomen CM, Ocke MC, Feskens EJ, et al. (2001) $\alpha$-Linolenic acid intake is not beneficially associated with 10 -y risk of coronary artery disease incidence: the Zutphen Elderly Study. Am J Clin Nutr 74, 457-463.

97. Lemaitre RN, Sitlani C, Song X, et al. (2012) Circulating and dietary $\alpha$-linolenic acid and incidence of congestive heart failure in older adults: the Cardiovascular Health Study. Am J Clin Nutr 96, 269-274.

98. Pan A, Chen M, Chowdhury R, et al. (2012) $\alpha$-Linolenic acid and risk of cardiovascular disease: a systematic review and meta-analysis. Am J Clin Nutr 96, 1262-1273.

99. Vedtofte MS, Jakobsen MU, Lauritzen L, et al. (2014) Association between the intake of $\alpha$-linolenic acid and the risk of CHD. Br J Nutr 112, 735-743.

100. Wilk JB, Tsai MY, Hanson NQ, et al. (2012) Plasma and dietary omega-3 fatty acids, fish intake, and heart failure risk in the Physicians' Health Study. Am J Clin Nutr 96, 882-888.

101. Fretts AM, Mozaffarian D, Siscovick DS, et al. (2013) Associations of plasma phospholipid and dietary $\alpha$-linolenic acid with incident atrial fibrillation in older adults: the Cardiovascular Health Study. J Am Heart Assoc 2, e003814.

102. Baxheinrich A, Stratmann B, Lee-Barkey YH, et al. (2012) Effects of a rapeseed oil-enriched hypoenergetic diet with a high content of $\alpha$-linolenic acid on body weight and cardiovascular risk profile in patients with the metabolic syndrome. Br J Nutr 108, 682-691.

103. Lichtenstein AH, Ausman LM, Carrasco W, et al. (1993) Effects of canola, corn, and olive oils on fasting and postprandial plasma lipoproteins in humans as part of a National Cholesterol Education Program Step 2 diet. Arterioscler Thromb 13, 1533-1542.

104. Pedersen A, Baumstark MW, Marckmann P, et al. (2000) An olive oil-rich diet results in higher concentrations of LDL cholesterol and a higher number of LDL subfraction particles than rapeseed oil and sunflower oil diets. J Lipid Res 41, 1901-1911.

105. Nielsen NS, Pedersen A, Sandstrom B, et al. (2002) Different effects of diets rich in olive oil, rapeseed oil and sunflower-seed oil on postprandial lipid and lipoprotein concentrations and on lipoprotein oxidation susceptibility. Br J Nutr 87, 489-499.

106. Carleton AJ, Sievenpiper JL, de Souza R, et al. (2013) Case-control and prospective studies of dietary $\alpha$-linolenic acid intake and prostate cancer risk: a meta-analysis. BMJ Open 3, 1-12.

107. Pelser C, Mondul AM, Hollenbeck AR, et al. (2013) Dietary fat, fatty acids, and risk of prostate cancer in the NIH-AARP diet and health study. Cancer Epidemiol Biomarkers Prev 22, 697-707.

108. Chajes V, Jenab M, Romieu I, et al. (2011) Plasma phospholipid fatty acid concentrations and risk of gastric adenocarcinomas in the European Prospective Investigation into Cancer and Nutrition (EPIC-EURGAST). Am J Clin Nutr 94, 1304-1313.

109. Shields PG, Xu GX, Blot WJ, et al. (1995) Mutagens from heated Chinese and U.S. cooking oils. J Natl Cancer Inst 87, 836-841.

110. Gladine C, Combe N, Vaysse C, et al. (2013) Optimized rapeseed oil enriched with healthy micronutrients: a relevant nutritional approach to prevent cardiovascular diseases. Results of the Optim'Oils randomized intervention trial. J Nutr Biochem 24, 544-549.

111. Obied HK, Allen MS, Bedgood DR, et al. (2005) Bioactivity and analysis of biophenols recovered from olive mill waste. J Agric Food Chem 53, 823-837.

112. Dermechea S, Nadoura M, Larrocheb C, et al. (2013) Olive mill wastes: biochemical characterizations and valorization strategies. Proc Biochem 48, 1532-1552.

113. De Leonardis A, Macciola V, Lembo G, et al. (2007) Studies on oxidative stabilisation of lard by natural antioxidants recovered from olive-oil mill wastewater. Food Chem 100, 998-1004. 
114. Lafka T-I, Lazou A, Sinanoglou V, et al. (2011) Phenolic and antioxidant potential of olive oil mill wastes. Food Chem 125, 92-98.

115. Fki I, Allouche N \& Sayadi S (2005) 3,4-Dihydroxyphenyl acetic acid from olive mill wastewater for the stabilization of refined oils: a potential alternative to synthetic antioxidants. Food Chem 93, 197-204.
116. Visioli F, Romani A, Mulinacci N, et al. (1999) Antioxidant and other biological activities of olive mill waste waters. J Agric Food Chem 47, 3397-3401.

117. Barnes AP, Wreford A, Butterworth MH, et al. (2010) Adaptation to increasing severity of phoma stem canker on winter oilseed rape in the UK under climate change. J Agric Sci 148, 683-694. 